者である，神戸市の財政逼迫による苦しい病院の 台所事情にもかかわらず，それを補って余りある 情熱で，若い医師を中心とするスタッフにより質 の高い循環器治療が行われ, 文字通り神戸市民の 健康を 24 時間支えている施設であると感じられ た.
最後に今回の施設見学の申し出を快く引き受 け，丁寧にご説明下さった盛岡先生，また山室先 生, 民田先生をはじめとする循環器内科の皆様, および，このような機会を与えて下さった日本循 環器学会の皆様に心よりお礼を申し上げます。

\title{
用語解説
}

\section{ApoE ノックアウトマウス}

ApoEノックアウトマウスはヒトにきわめ て類似した動脈硬化病変を形成してくること より, 動脈硬化の標準的モデルとして近年研 究に広く用いられている.

ApoE（apolipoprotein E)は, 299個のア ミノ酸から成る分子量 $34 \mathrm{kD}$ の糖蛋白質で あり，キロミクロンレムナント，VLDL， LDL, HDL などのリポ蛋白質の主要な構成 成分である.ApoEは，リポ蛋白質レセプタ との結合だけでなく，コレステロール逆転送 系にも重要と考えられており，ApoE 異常 は，動脈硬化惹起性リポ蛋白質として注目さ れている。

$\mathrm{ApoE}$ ノックアウトマウスは $\mathrm{ApoE}$ 欠損症 の疾患モデルであり, 普通食投与でも，8週
齢で単球の接着および内皮下への侵入, 10 週龄以降で泡沫細胞集積が認められ, 高コレ ステロール食投与では， 6 週齢で単球の接着 および内皮下への侵入が，8週龄以降で泡洙 細胞集積が, さらに15週齢で線維性プラー クが出現する.ApoEはリポ蛋白質の特異的 レセプタを介して，レムナントの代謝と動脈 硬化発症に重要な役割を担っていると考えら れ，ApoEノックアウトマウスなどの動脈硬 化惹起性遺伝子ノックアウトマウスや遺伝子 トランスジェニックマウスを利用して, 動脈 硬化の研究が今後ますます行われるであろ う.

(駿河台日本大学病院循環器科

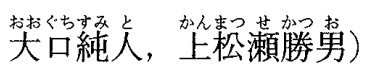

